\title{
Parasitic Contamination of Local Drinking Water Sources in Aba Metropolis, Abia State, Nigeria
}

\author{
Blessing U. Ejike ${ }^{1,2}$, Carmelita C. Ohaeri ${ }^{2}$ and Ebube C. Amaechi ${ }^{3 *}$
}

\begin{abstract}
${ }^{1}$ Department of Biology/Microbiology, Abia State Polytechnic, Aba Abia State, Nigeria; ${ }^{2}$ Department of Zoology and Environmental Biology, Michael Okpara University of Agriculture, Umudike, Abia State, Nigeria; ${ }^{3}$ Department of Zoology, Faculty of Life Sciences, University of Ilorin, Ilorin, Nigeria. *Email: ebubeamechi@yahoo.com.
\end{abstract}

\begin{abstract}
Water-borne parasitic infections have become a source of concern in recent times due to the contamination of various water sources. A survey on the parasitic contamination of local drinking water sources in Aba metropolis was carried out between August and October 2018. This was done to evaluate the extent of contamination of these water sources and their public health implications. A total number of eighty (80) water samples were investigated from five (5) major water sources within the study area using the standard sedimentation method and examined for parasite cysts, eggs and larvae. Physical/macroscopic examination was done to determine the $\mathrm{pH}$, colour, odour, temperature and presence/absence of particles. Among the water sources analyzed, stream water samples had the highest rate of parasite contamination $27(44.3 \%)$ followed by river water $14(22.9 \%)$ while the least contaminated was borehole $7(11.5 \%)$. Rainwater was found free from parasitic infestation. The differences in the level of contamination among the water sources analyzed were found to be statistically significant $(\mathrm{P}<0.05)$. Five parasites Entamoeba histolytica, Giardia lamblia, Ascaris lumbricoides of Entamoeba coli and Hookworm were observed. Each of the sample sources except rainwater harbored at least one of these. Among these parasites, Giardia lamblia had the highest rate occurrence of 15 (24.6\%), followed by Entamoeba histolytica 14 (22.9\%) and the least frequently occurring parasite was hookworm $8(13.1 \%)$. Most of the identified water sources are utilized by the populace who lack access to potable water. The detection of protozoan and helminthic parasites in drinking water sources is a serious public health concern, hence the proper implementation of a supply of safe drinking water is vital.
\end{abstract}

Keywords: Parasitic; Contamination; Local sources; Drinking water and Aba metropolis.

$$
\text { التلوث الطفيلي لماء الثرب في أباميتروبوليس، ولاية أبيا، نيجيريا }
$$

\footnotetext{
الملخص: يشكل التلوث الطفيلي في مصادر المياه مشكلة حيوية. ولذللك أجرينا دراسة للتلوث الطفيلي لمصادر مياه الثرب الثرب المحلية في أبا ميتروبوليس بين

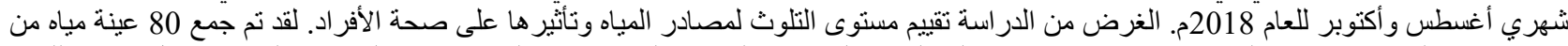

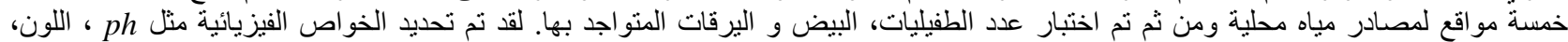

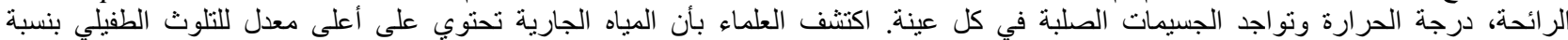

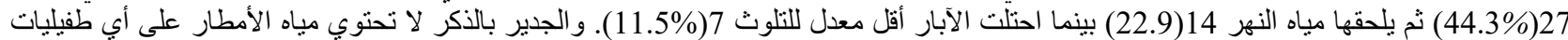

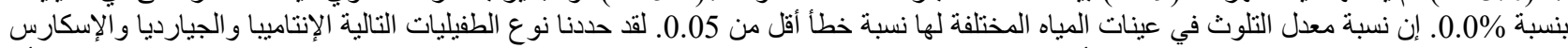

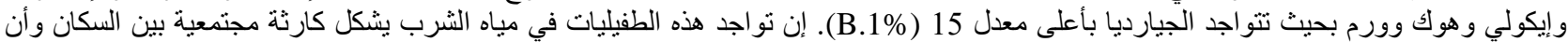

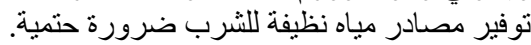
الكلمات المفتاحية: طفيليات، التلوث، مصادر محلية، مياه الثرب، أباميترو بوليس.
} 


\section{BLESSING UZOAMAKA EJIKE ET AL.}

\section{Introduction}

W ater is universal and fundamental to the survival and wellbeing of living organisms. Water-borne diseases are usually acquired by the consumption of polluted water containing human and animal faecal matter from patients or healthy carriers and they remain a major source of morbidity and mortality in the world causing more than 2.2 million deaths per year [1]. Sources of water for human use include boreholes, well water, dams, rivers, streams, lakes, municipal water and rain water [2]. Most of these water sources are located some distance away requiring transportation to homes. These different sources of water need to be protected from pollution and contamination by potential parasites, micro-organisms and harmful chemical substances [3]. Most urban and rural communities in the developing countries do not have adequate disposal systems for human waste, and many inhabitants defecate indiscriminately in places not far from their dwelling places, including the sides of streams, home ponds, wells, and in some cases into the streams [4]. Furthermore, excreta from children and free roaming animals are particularly hazardous and a potential source of health problems in both urban and rural communities [5]. According to Water Aid (2012) over 2000 children die of diarrhea in Africa daily. Epidemics associated with water-borne diseases are common in most developing countries where access to basic amenities, especially safe drinking water, is lacking. Potable water should be free from biological or chemical contaminants. It must be colourless, tasteless and odourless in accordance with the recommendations of World Health Organization [6]. However, according to [7], in most developing countries like Nigeria, dangerous and very toxic wastes are disposed of by dumping them in rivers and streams with total disregard for aquatic life and rural dwellers. Lack of information about the parasitic and pathogenic microorganisms in drinking water sources in our rural communities creates uncertainties in our understanding of the overall quality of the drinking water in these areas, and as a result, has prompted the need to undertake this research in accordance with the goal of the WHO on safe drinking water. To the best of our knowledge, no documented report has been made on parasitic contamination of local sources of drinking water in Aba metropolis, Abia State, Nigeria and its public health implications

\section{Materials and method}

\subsection{Study area}

The study was carried out in Aba metropolis. Aba is a major settlement and commercial centre surrounded by small villages and towns in the southeast of Nigeria. It is the largest clan and the main trading centre in Abia State. Aba is divided into two local government areas namely Aba South and Aba North. Other local government areas are AbOsisioma and Obingwa Local Government Areas. Aba has a population of 2,434, 265 as at the 2006 census [8] and is located between latitudes $5^{\circ} 07^{\prime} \mathrm{N}$ and longitude $7^{\circ} 22^{\prime} \mathrm{E}$. Aba North has its headquarters located in the town of Eziama. Aba South has its headquarter in the city of Aba. It is characterized by a tropical climate with distinct dry and rainy seasons spanning from November to March and April to October respectively. The average temperature is $27{ }^{\circ} \mathrm{C}$, the average humidity $90 \%$ and the annual rainfall $2,400 \mathrm{~mm}$. The major crops cultivated in the area are yam, cassava, plantain and vegetables. The area is still developing, hence, adequate social and infrastructural amenities are lacking. Sources of water for drinking and other domestic activities in the area include boreholes, streams, rivers, rain water and in some villages, well water.

\subsection{Ethical approval}

A letter of introduction was obtained from the Head of the Department of Biology/ Microbiology, Abia State Polytechnic, Aba, Abia State before the commencement of this work. Permission of the authorities in charge was obtained for collection of water samples, after explaining the aim of the study.

\subsection{Sample Collection}

Ten samples each from five (5) different water sources were collected using sterile $500 \mathrm{ml}$ glass bottles. Each of the samples was collected at a different location within the different communities in 10 trips except for the rainwater which was collected each time rain fell during the period of the study. The samples which were collected between the months of August and October, 2018 include borehole water from randomly selected sampling sites in Osusu, Umungasi and Eziama, in Aba North Local Government Area; stream water from Okpulo-Umobo and Eziama in Osisioma Ngwa and Aba North Local Government Area respectively; shallow and deep well water, from Umuocheala village in Osisioma Ngwa Local Government Area, river water from Ogbor Hill, in Aba South Local Government Area and rain water from Umuocham community, Aba South Local Government Area, all in Aba metropolis. Samples of water from the stream and river were collected during the early hours of the day (at about 9:00 am in the morning). The base of the sample bottle was held in one hand and the cap was carefully opened with the other hand covered with gloves and then plunged downwards below the surface of the water. Samples of water from the boreholes were obtained by first sterilizing the mouth of the tap and allowing water to run for a few minutes before collecting water into the sample bottles. Samples of water from the wells were obtained with help of the villagers who were given clean gloves to fetch water from each of the wells. The base of the sample bottle was held in one hand, the cap was carefully opened with the other hand and some of the water was carefully poured into the sample bottle. A total of 80 water 


\section{PARASITIC CONTAMINATION OF LOCAL DRINKING WATER SOURCES}

samples (30 Borehole water samples from three different communities, 20 stream water samples from two communities, 10 river and well water samples from one community each and 10 samples of rain water from an autonomous community) were collected for the study and were transported to the Department of Biology/Microbiology laboratory within two (2) hours (maximum transit time) of collection to Abia State Polytechnic Aba, Abia State for examination and analysis.

\subsection{Parasitological analysis}

Each of the water samples was first subjected to macroscopic and physical examination to determine the $\mathrm{pH}$ using a $\mathrm{pH}$ meter, the temperature using a thermometer, the colour, the odour and the presence/ absence of debris. The water samples in each labeled container were shaken and passed through a filter sieve of 0.5 mesh size according to WHO guidelines. The filter was removed and particulate materials present discarded. The filtrate was poured into $10 \mathrm{ml}$ centrifuge tubes and centrifuged at $2500 \mathrm{rpm}$ per minutes for 10 minutes. The test tubes were allowed to settle for a while after which the supernatant was discarded. A drop of the suspended sediment was placed on a clean grease free glass slide with a drop of Lugol's iodine solution using a Pasteur pipette. The mixture was covered with a cover slip and examined microscopically using x10 and x 40 objective lenses to identify parasite eggs, larvae and cysts[9].

\subsection{Data analysis}

Comparative analysis of parasites in the various water samples was done using SPSS package version 22.0. The statistical analysis for significant differences was done using chi-square $\left(\mathrm{X}^{2}\right)$ placed at a significant level of $\mathrm{p}<0.05$.

\section{Results}

A total of eighty (80) water samples were collected from streams, boreholes, rivers, wells and rain water, out of which five (5) different parasites (protozoan and helminthes) were found. The species of parasites were in various stages of development, ranging from eggs and cysts to larvae. The macroscopic and physical examination of the various water samples showed that the temperatures of all the water samples were within the range of $27^{\circ} \mathrm{C}$ and $29{ }^{\circ} \mathrm{C}$ and the $\mathrm{pH}$ values were within the range of 6.0-7.1. All the water samples analyzed except the well water were colourless and odourless. The stream, river and the well-water samples contained particles while the others were clear and particle-free (Table 1). All the water sources except the rainwater from Umuocham recorded at least two waterborne parasites. Out of the five (5) different parasites encountered in this study, Giardia lamblia was observed to have the highest rate of occurrence $15(24.6 \%)$ followed by Entamoeba histolytica which occurred at the rate of $14(22.9 \%)$, Hookworm was the least frequently occurring parasite $8(13.1 \%)$ as shown in Table 2 . Among the water sources, the streams had the highest rate of contamination with parasites $27(44.3 \%)$ followed by the rivers $14(22.9 \%)$ while the least contaminated were the boreholes $7(11.5 \%)$. Rain water had no parasite contamination $0(0.0 \%)$ as shown in Figure 1. The differences in the level of contamination among the water sources were statistically significant $(\mathrm{P}<$ $0.05)$.

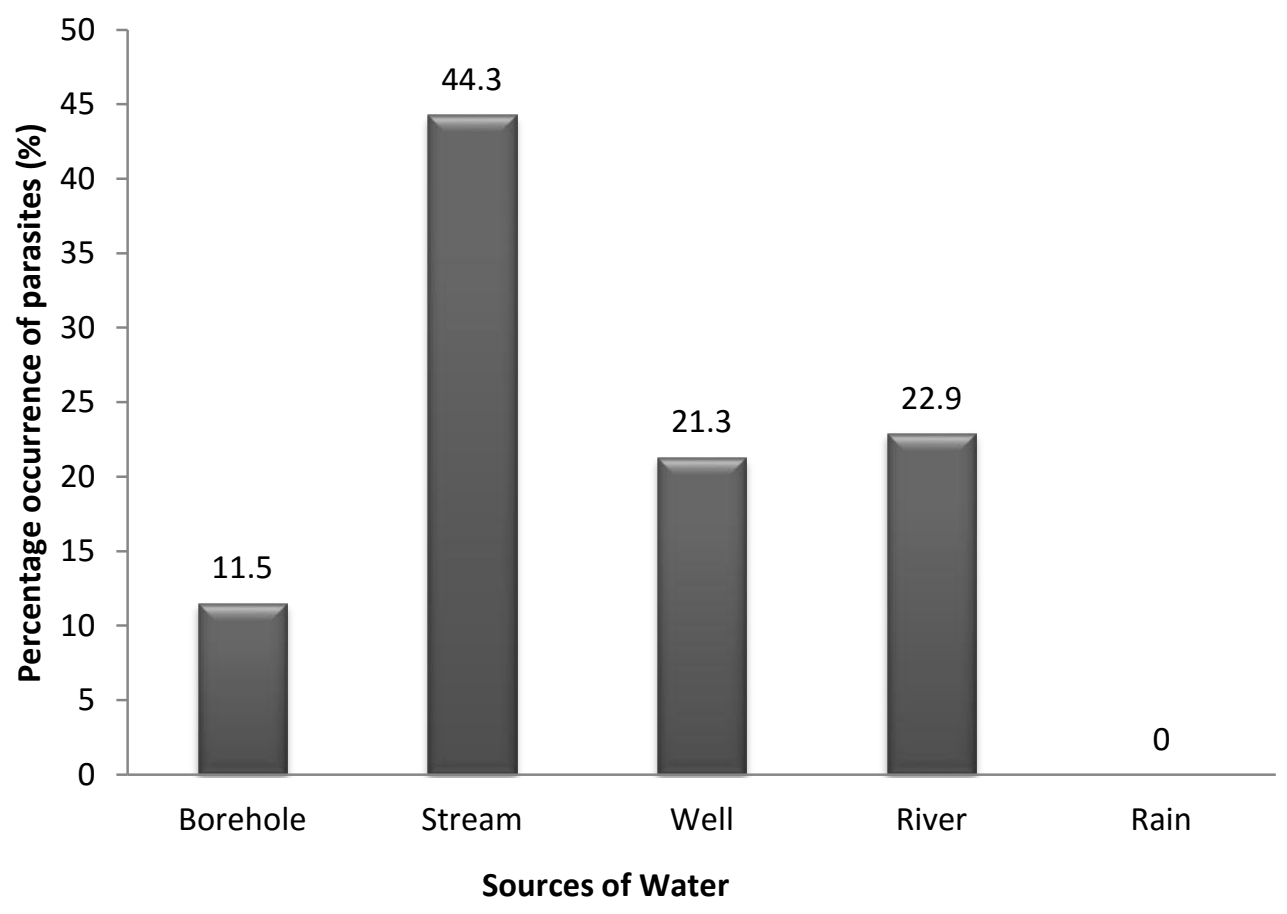

Figure 1. Percentage occurrence of parasites in the drinking water sources. 
BLESSING UZOAMAKA EJIKE ET AL.

Table 1. Macroscopic/Physical parameters of the local water sources in Aba metropolis.

\begin{tabular}{|c|c|c|c|c|c|}
\hline Water Sources & Temperature & pH & Colour & Odour & Clear/ particles \\
\hline $\begin{array}{c}\text { Borehole } \\
\text { (Osusu) }\end{array}$ & $28^{\circ} \mathrm{C}$ & 7.1 & Colourless & Odourless & $\begin{array}{l}\text { Clear without } \\
\text { particles }\end{array}$ \\
\hline $\begin{array}{c}\text { Stream } \\
(\mathrm{Okpu}-\mathrm{Umobo})\end{array}$ & $27^{\circ} \mathrm{C}$ & 7.0 & Colourless & Odourless & $\begin{array}{l}\text { Clear with brownish } \\
\text { particles }\end{array}$ \\
\hline $\begin{array}{l}\text { Borehole } \\
\text { (Eziama) }\end{array}$ & $28^{\circ} \mathrm{C}$ & 6.9 & Colourless & Odourless & $\begin{array}{l}\text { Clear without } \\
\text { particles }\end{array}$ \\
\hline $\begin{array}{c}\text { Borehole } \\
\text { (Umungasi) }\end{array}$ & $28^{\circ} \mathrm{C}$ & 6.9 & Colourless & Odourless & $\begin{array}{l}\text { Clear without } \\
\text { particles }\end{array}$ \\
\hline $\begin{array}{c}\text { Stream } \\
\text { (Eziama) }\end{array}$ & $27^{\circ} \mathrm{C}$ & 6.5 & Colourless & Odourless & Clear with particles \\
\hline $\begin{array}{c}\text { Well } \\
\text { (Umuocheala) }\end{array}$ & $27^{\circ} \mathrm{C}$ & 6.5 & $\begin{array}{c}\text { Pale yellowish } \\
\text { brown }\end{array}$ & Odourless & $\begin{array}{l}\text { Not clear with } \\
\text { brownish particles }\end{array}$ \\
\hline $\begin{array}{c}\text { Rain } \\
\text { (Umuocham) }\end{array}$ & $26^{\circ} \mathrm{C}$ & 6.9 & Colourless & Odourless & $\begin{array}{l}\text { Clear without } \\
\text { particles }\end{array}$ \\
\hline $\begin{array}{c}\text { River } \\
\text { (Ogbor-hill) }\end{array}$ & $27^{\circ} \mathrm{C}$ & 6.0 & Colourless & Odourless & $\begin{array}{l}\text { Clear with whitish } \\
\text { particles }\end{array}$ \\
\hline
\end{tabular}

Table 2. Rate of occurrence of parasites in relation to the water sources in the study area.

\begin{tabular}{|c|c|c|c|c|c|c|c|c|}
\hline $\begin{array}{c}\text { Water } \\
\text { Sources }\end{array}$ & $\begin{array}{l}\text { No of } \\
\text { samples }\end{array}$ & $\begin{array}{l}\text { Ascaris } \\
\text { lumbricoides }\end{array}$ & E. coli & G. lamblia & E. histolytica & $\begin{array}{l}\text { Hook- } \\
\text { worm }\end{array}$ & Total & $\begin{array}{l}\text { Percentage } \\
\text { occurrence } \\
(\%)\end{array}$ \\
\hline $\begin{array}{l}\text { Borehole } \\
\text { (Osusu) }\end{array}$ & 10 & '0 & 0 & 2 & 1 & 0 & 3 & 4.9 \\
\hline $\begin{array}{l}\text { Stream } \\
\text { (Okpu- } \\
\text { Umobo) }\end{array}$ & 10 & 3 & 3 & 4 & 3 & 2 & 15 & 24.6 \\
\hline $\begin{array}{l}\text { Borehole } \\
\text { (Eziama) }\end{array}$ & 10 & 0 & 0 & 1 & 0 & 1 & 2 & 3.3 \\
\hline $\begin{array}{c}\text { Borehole } \\
\text { (Umungasi) }\end{array}$ & 10 & 0 & 0 & 1 & 1 & 0 & 2 & 3.3 \\
\hline $\begin{array}{c}\text { Stream } \\
\text { (Eziama) }\end{array}$ & 10 & 3 & 3 & 2 & 2 & 2 & 12 & 19.7 \\
\hline $\begin{array}{c}\text { Well } \\
\text { (Umuocheala } \\
\text { ) }\end{array}$ & 10 & 3 & 4 & 2 & 3 & 1 & 13 & 21.3 \\
\hline $\begin{array}{c}\text { Rain } \\
\text { (Umuocham) }\end{array}$ & 10 & 0 & 0 & 0 & 0 & 0 & 0 & 0 \\
\hline $\begin{array}{c}\text { River } \\
\text { (Ogbor-hill) }\end{array}$ & 10 & 2 & 3 & 3 & 4 & 2 & 14 & 22.9 \\
\hline $\begin{array}{c}\text { Total } \\
(\%)\end{array}$ & 80 & $\begin{array}{l}\mathbf{1 1} \\
18.0\end{array}$ & $\begin{array}{l}\mathbf{1 3} \\
21.3\end{array}$ & $\begin{array}{l}15 \\
24.6\end{array}$ & $\begin{array}{l}14 \\
22.9\end{array}$ & $\begin{array}{l}\mathbf{8} \\
13.1 \\
\end{array}$ & 61 & 100 \\
\hline
\end{tabular}

\section{Discussion}

Water sources contaminated with parasites are a threat to millions of people in developing countries, which result in severe morbidities and mortalities [1]. The prevalence of water-borne diseases is determined by the quality of drinking water. In this study, most of the drinking water sources were contaminated with water-borne parasites. These parasites were found in the different sources of drinking water at various rates of occurrence. The rural communities of the study area are therefore at risk of water-borne diseases due to the high rate of parasitic infestation of these water sources. This finding agrees with the reports of [10] and [11] who recorded degrees of contamination of local sources of drinking water in Ebonyi State and Nassarawa State, respectively. This is explained by the fact that natural bodies of water such as lakes, rivers and groundwater normally contain nutrients and certain microorganisms (bacteria, viruses, etc.) which have evolved to take advantage of this environment [12]. Surface and ground water are subject to contamination by enteric water-borne pathogens which may come from leaking septic systems or improperly protected 


\section{PARASITIC CONTAMINATION OF LOCAL DRINKING WATER SOURCES}

well heads. The presence of water-borne parasites in natural water bodies helps explain the tolerance adaptation of these parasites even to harsh conditions. The public health implication of these results is that water-borne parasites pose a serious hazard to human health and may result in outbreaks of water-borne diseases among the community dwellers.

With the exception of well water and the river water, the physical parameters (temperature and $\mathrm{pH}$ ) of the different water sources were slightly below the recommended limits of WHO [1] and Nigerian Standard for Drinking Water Quality (NSDWQ) [13] which is a pH range of 6.5-8.5. The river water with a pH of 6.0 suggests slight acidity of the water sample which could likely be due to the presence of organic matter such as microorganisms which generate excessive levels of carbon (iv) oxide [14]. The importance of water $\mathrm{pH}$ is to keep the body in balance and regulate metabolic processes. Water with $\mathrm{pH}$ values less than or greater than 7 may cause aesthetic problems, hence the body is constantly working to achieve a balanced $\mathrm{pH}$ level [4]. The health implication of this is that the physical appearance of water, especially groundwater and surface water, does not guarantee its safety for drinking. The temperature values of all the water samples recorded ranged from $27{ }^{\circ} \mathrm{C}$ to $29{ }^{\circ} \mathrm{C}$; these values were lower than the WHO stipulated maximum temperature level of $40^{\circ} \mathrm{C}$ for potable water [1]. Aside from the temperature and $\mathrm{pH}$, colour in drinking water indicates the presence of organic substances such as humic substances while odour in water is caused by increased biological activity [1]. Some of the water samples contained dirt and particles while others contained some coloured particles, as a result making the water unfit for drinking. The activities that go on within the area of these water sources, in addition to erosion and influx of surface water, could be reasons for their contamination [10]. Three (3) water-borne protozoan parasites, Entamoeba coli, Giardia lamblia, Entamoeba histolytica and two (2) helminth parasites, hookworm, and Ascaris lumbricoides were identified in this study. The parasites were seen as fertilized eggs, cysts and larvae. The identification of these parasites agrees with the studies carried out by [10] in Ebonyi State, Nigeria and [14] in Ankara, Turkey on their drinking water sources. The public health implication of this finding is that water-borne parasite infections are considered a re-emerging threat. In developing countries like Nigeria, water-borne parasites and protozoan pathogens such as Cryptosporidium parvum, Giardia lamblia, Entamoeba histolytica, and many others are frequently associated with morbidity particularly in children. Theses parasites are also the most common cause of infections worldwide $[15,16]$. The World Health Organisation estimates that $88 \%$ of the burden of water related infections is attributed to unsafe water supply, sanitation and hygiene [2].

Of all the water sources analyzed, the stream, river and well water were the most contaminated. This is not surprising because contaminants gain access into water bodies through human and animal faecal matter from patients and healthy carriers of parasitic diseases [4]. Most of the inhabitants of Eziama community, particularly those who live few meters away from the stream do not have adequate disposal systems for human waste, and as such defecate indiscriminately in places not far from their dwelling places, including directly on the soil or by the sides of the streams. This finding is similar to the report of [17] who observed that well water, pond and stream were the most contaminated water sources in some local government areas of Plateau State, Nigeria and [11] who also found out that a well water source had the highest prevalence rate of parasites in Lafia Local Government Area, Nasarawa State, Nigeria. Transmission of parasites occurs when water is contaminated with the parasites [15]. Excreta-related communicable diseases have also become a major problem in areas where untreated human faeces are used as manure as they are regularly washed into the communities' water bodies [5]. Unprotected surface water (such as rivers) or ground water (such as shallow wells) can become contaminated by human or animal faeces or agricultural effluent [15]. The data from this study also showed that borehole water was not completely free from water-borne parasites. The recovery of protozoan cysts in the samples analyzed clearly demonstrated the continued deterioration of the environment brought about by poor planning and uncontrolled property development in the area. A borehole that was sunk below 10 meters is more prone to faecal pollution from landfill and septic tank seepages and this is particularly true if the recharge point is located very close to the pit [16]. Samples from rain water were found to be free from parasites; this is because water obtained from rainfall is usually covered after collection and was not fetched directly under the roof of the houses. This does not agree with the fact that parasitic infestation of water is contaminative. Human parasites do not directly use water bodies for their life cycle development, rather, their vectors inhabit and associate their transmission with these water bodies [14].

Giardia lamblia accounted for the most frequently occurring parasites in this study. Giardia lamblia cysts may remain viable in water for long periods of time under typical environmental conditions depending on source water characteristics and water treatment practices [18]. Its survival in water is dependent primarily on decreased water temperature [19]. Protozoan cysts like Entamoeba histolytica cysts can survive in water for several weeks [20,21,22].Ascaris lumbricoides eggs and hookworm larvae were observed in this study. According to [20,21] helminthic ova can remain alive in cold water for months. The occurrence of intestinal parasites in water sources is prevalent among poor people in remote rural communities who lack proper toilet facilities, an adequate supply of potable drinking water and poor sewage and waste disposal systems [22]. The implications of these findings suggest that parasitic organisms are maintained by a viable ecosystem in remote settlements in Nigeria, where toilet facilities, pipe borne water, poor sewage disposal, and illiteracy thrive the most. 


\section{BLESSING UZOAMAKA EJIKE ET AL.}

\section{Conclusion}

The results showed the extent of parasitic contamination of the various drinking water sources in Aba metropolis and the susceptibility of the population to water-borne diseases. Since almost all the water samples had varying levels of parasitic contamination, provision of well-treated potable water combined with the application of adequate operational practices are of utmost importance within the area and the state in general. The inhabitants of the area should also stop activities that lead to the contamination of the water bodies and boil their drinking water before consumption. Infections by these parasites can result in serious parasitic diseases such as amoebic dysentery and gastrointestinal infection which may pose health risks as well as result in economic losses.

\section{Conflict of interest}

The authors declare no conflict of interest.

\section{Acknowledgement}

The authors are sincerely grateful to the technical staff at the Microbiology laboratory, Department of Biology/Microbiology, Abia State Polytechnic, Aba, where this research was conducted, for their effort towards making it a success.

\section{References}

1. World Health Organization. Guidelines for Drinking Water Quality. Water Safety and Quality. ${ }^{\text {th }}$ Edition incorporating the $1^{\text {st }}$ addendum by World Health Organisation. 2011 Retrieved 2019-08-02.

2. World Health Organization 2008. Guidelines for Drinking Water Quality. Safe Water and Global Health. $3^{\text {rd }}$ Edition by World Health Oragnisation. 2008. Retrieved 2019-08-05.

3. Yousefi, Z., Ziaei-hezarjaribi, H., Enayati, A.A. and Mohammadpoor, R.A. Parasitic Contamination of Wells Drinking Water in Mazandaran Province. Iranian Journal of Environmental Health Science and Engineering, 2009, 6(4), 241-246.

4. Adegoke, A. The Challenges of Environmental Management in Africa. The Nigeria Experience. An International Journal of Medical Science, 2000, (2), 3.

5. Ukoli, F.A. M. Sanitation in Africa: Nigeria. An International Journal of Medical Science, 2000, (2), 25-28.

6. World Health Organisation.WHO Guidelines for Drinking Water Quality. 2015. Retrieved July 21 ${ }^{\text {st }} 2019$, from https://www.WHOguidelinesfordrinkingwaterquality.

7. Curry, A. and Smith, H.V. Emerging Pathogens: Isospora, Cyclospora and Microsporidia. Parasitology, 1998, 117, 143-159.

8. National Population Commission of Nigeria (2006). Volume 1 of the national population census, Pp 15. Accessed December 15, 2019, from http://www.population.gov.ng/index.php/80-puplications.

9. Cheesbrough, M. District Laboratory Practice in Tropical Countries Part I. Cambridge University press, United Kingdom, 2004, 178-209.

10. Odikamnoro, O.O., Omowaye, O.S. and Udu-Ituma, S.O. Parasitic survey of drinking water source in Ohaukwu Local Government Area, Ebonyi State, Nigeria. European Journal of Nursing, 2014, 1(1), 1-5.

11. Gyang, P.R., Uzoigwe, N.R., Ayim, J.O., Ombugadu, A. and Ahmed, H.O. Evaluation of local drinking water sources to determine their possible contamination with parasite in Lafia Local Government Area Nasarawa State, Nigeria. European Journal of Basic and Applied Sciences, 2017, 4(1), 63-68.

12. World Health Organization. Guidelines for the safe use of waste water, excreta and greywater-volume; waste water use in agriculture WHO, Geneva, 2006.

13. Standards Organization of Nigeria (SON), Nigerian Standard for drinking water quality, SON Publication, Abuja, Nigeria, 2007, 15-16.

14. Bakir, B., Tanyukseel, M., Saylam, F., Tanriverdis, S., Araz, R.E., Hacim, A.K. and Hasde, M. 2003. Investigation of Waterborne Parasites in Drinking Water Source of Ankara, Turkey. Journal of Microbiology, 2003, 41(2), 148-151.

15. Efstratiou, A., Ongerth, J.E. and Karanis, P. Water-borne transmission of protozoan parasites: Review of worldwide outbreaks - An update 2011-2016. Water Research, 2017, 114, 14-22.

16. Tanyuksel, M., Tachibana, H. and Petro, W.A. Amoebiasis, an Emerging Disease. American Society of Microbiology, 2001, 1, 197-212.

17. Chollom, S.C., Iduh, M.U., Gyang, B.J., Idoko, M.A., Ujah, A., Aga, G.O., Peter, J., Akele, Y.R. and Okwori, J. A. 2013. Parasitological Evaluation of Domestic Water Sources in a Rural Community in Nigeria. British Microbiology Research Journal, 2013, 3(3), 393-399.

18. Jones, J.G. Freshwater ecosystems-structure and response. Ecotoxicology and Environmental Safety, 2001, 50, 107-13.

19. Centers for Disease Control and Prevention. Safe Water System for the Developing World: A handbook for implementing Household-Based Water Treatment and Safe storage projects, Atlanta, G.A., USA, p187. 2000. 


\section{PARASITIC CONTAMINATION OF LOCAL DRINKING WATER SOURCES}

20. Aroh, K.N., Sagay, H.O., Obieze, C.C., Ubong, I.U., Eze, C.L. and Abam, T.K.S. A survey of bore hole water quality for possible water-borne parasites in Diobu Community in Southern Nigeria. African Journal of Environmental Pollution and Health, 2006, 5(1), 16-22 .

21. Arnold, B.F. and Colford, J.M. Treating water with chlorine at point- of -use to improve water quality and reduce child diarrhea on developing countries. A systematic review and meta - analysis. American. Journal of Tropical Medicine and Hygiene, 2007, 76, 354-365.

22. Eseigbe, A.P., Ibhadode, O., Ayoola, A.R. and Sosanolu, O.M. Experimental Determination of Drinking Water Quality in Abeokuta Metropolis, South-Western Nigeria. International Journal of Advances in Scientific Research and Engineering, 2018, 4(12), 241-6.

Received 31 August 2020

Accepted 14 January 2021 